\title{
The epidemiology and antigenic characterization of influenza viruses isolated in Curitiba, South Brazil
}

\author{
Luine RR Vidal $/{ }^{1}{ }^{+}$, Marilda M Siqueira ${ }^{2}$, Meri B Nogueira, Sonia M Raboni, Luciane A Pereira, \\ Gislene RA Takahashi, Indianara Rotta, Maria do Carmo Debur, Libera M Dalla-Costa ${ }^{1}$
}

Laboratório de Virologia 'Laboratório de Biologia Molecular para Doenças Infecciosas, Hospital de Clínicas, Universidade Federal do Paraná, R. Padre Camargo 280, 80060-240 Curitiba, PR, Brasil 'Laboratório de Vírus Respiratórios, Instituto Oswaldo Cruz-Fiocruz, Rio de Janeiro, RJ, Brasil

Several studies conducted all over the world have reported that the influenza virus is associated with great morbidity and mortality rates. In this study, we analyzed the incidence of the influenza virus between 2000 and 2003 in Curitiba. We studied 1621 samples obtained from outpatients and hospitalized patients of both sexes and all ages. The study was conducted at the local primary care health units (outpatients) and at the tertiary care unit (hospitalized) of the General Hospital of the Federal University in the state of Paraná, Brazil. Nasopharyngeal aspirates and, eventually, bronchoalveolar lavage were assayed for the presence of viral antigens, either by indirect immunofluorescence or cell culture. Of the samples studied, 135 (8.3\%) were positive for influenza virus, and of those, 103 (76.3\%) were positive for type A and 32 (23.7\%) for type B. Additionally, positive samples were analyzed by reverse transcription followed by polymerase chain reaction and subtypes $\mathrm{Hl}$ and $\mathrm{H} 3$ were identified from this group. A high incidence of positive samples was observed mainly in the months with lower temperatures. Furthermore, outpatients showed a higher incidence of influenza viruses than hospitalized patients.

Key words: influenza virus - incidence - seasonality - antigenic characterization

Several studies conducted all over the world have reported that the influenza virus (FLU) is associated with high morbidity and mortality rates (Cox et al. 1998). FLUs are a significant cause of respiratory infections in individuals of all ages. However, young children, old people, and immunosuppressed patients may develop complications such as pneumonia, which may occasionally be fatal (Monto 2002). Influenza infection occurs in a seasonal pattern and leads to an extensive burden of disease. One characteristic of seasonal influenza activity is that it leads to excess or "hidden" deaths. These are deaths that are not usually attributed to influenza infection, even though many of them are caused by either viral or bacterial pneumonia, secondary to influenza infection (Zambon 1999). During the winter months, as many as $19 \%$ of adults who are hospitalized with acute respiratory disease complaints have active influenza infection. Influenza leads to job and school absenteeism, and is also associated with up to 20,000 deaths per year in the United States alone (Neuzil et al. 2001) High rates of mortality and morbidity attributed to respiratory diseases occur all over the world equallyas well as in Curitiba, state of Paraná (PR), Southern Brazil, according to the local health department (Ministério da Saúde 2002). The aim of this study was to evaluate the incidence of the

Financial support: UFPR, Fiocruz

+ Corresponding author: virologiahc@ufpr.br

Received 12 September 2007

Accepted 25 March 2008
FLU and the seasonality of respiratory infections among both outpatients and hospitalized patients.

This study was conducted during the period from 2000 to 2003 using nasopharyngeal aspirates (NPA) or bronchoalveolar lavage (BAL) samples. The samples were analyzed by immunofluorescence (IF), cell culture (CC), and reverse transcription followed by polymerase chain reaction (RT-PCR) at the Virology laboratory of the General Hospital at the Federal University in state PR, Brazil.

\section{PATIENTS, MATERIALS AND METHODS}

Studied population - This study was conducted as part of the Influenza Surveillance Programme of the Brazilian health service. It was extended for hospitalized patients. The study was performed at the local primary health care units (outpatients) of the public health service from Curitiba and at the tertiary care unit (hospitalized) of the General Hospital at the Federal University in PR, Brazil. Hospitalized patients included bone marrow transplant (BMT) patients and pediatrics patients (emergency, infectology and intensive care units). Subjects of all ages and both sexes were attended at the both services in the period from 2000 to 2003.

Outpatients - These patients were included in the study based on following clinical criteria, compatible with influenza-like illness: fever $\left(>39^{\circ} \mathrm{C}\right)$, rhinorrea, congestion, sore throat, myalgia, eye or ear pain, and malaise with a maximum duration of five days. Selected patients were required to present fever and at least one respiratory and one systemic symptom. Patients who had previously received an influenza vaccine were included in the project. Samples were selected twice a week on 
wednesday and thursday during the period of the study. An epidemiological questionnaire was also made and transported with the sample.

Hospitalized - These patients were considered eligible after analysis by a physician based on the presentation of signs and symptoms compatible with acute respiratory illness (ARI) of possible viral etiology. Samples were obtained from Pediatrics Units, such as, the intensive care unit, and the emergency, infectology, and BMT units.

Clinical samples - The NPA were obtained by aspiration, as described previously (Gardner \& Mcquillin 1968) In some cases, BAL was collected. Samples were transported immediately to the virology laboratory on ice in a container, stored between $2-8^{\circ} \mathrm{C}$ and processed within $6 \mathrm{~h}$. Sample preparation was performed by adding $2 \mathrm{ml}$ of transport medium (Tryptose Broth), followed by centrifugation. The supernatant was subsequently separated into two aliquots, one for viral culture and the other for molecular methodologies. The first aliquot was treated with antibiotics $(10 \mu \mathrm{g} \mathrm{B}$ amphotericin, $50 \mathrm{U} / \mathrm{ml}$ penicillin and $0.2 \mathrm{mg} / \mathrm{ml}$ streptomycin) to avoid microbial contamination, and inoculated into the appropriate cellular lineage. The second aliquot was stored at $-70^{\circ} \mathrm{C}$ for testing using molecular procedures. The NPA/BAL cell pellet was assayed for the presence of viral antigens by indirect IF. The study was approved by the Ethical and Research Committee for Human Beings from Paraná Federal University (protocol number: CEP-HC 367.077/2001-06).

Viral antigenic detection by indirect IF - The detection of viral antigens was performed by IF to identify respiratory syncytial virus (RSV), adenovirus (Adeno), parainfluenza types $1,2,3$ (PIV) and influenza A (FLUA) or B antigens (FLUB) in NPA/BAL. For in Mardin Darby Canine Kidney (MDCK) cells harvested from viral cultures, we assayed for FLUA and FLUB antigens. Cells affixed to glass slides were fixed in cold acetone, then incubated with the appropriate dilution of monoclonal antibodies against the respiratory viruses listed above (Chemicon, USA) for $30 \mathrm{~min}$ at $37^{\circ} \mathrm{C}$. Following a wash with PBS, a second incubation with a fluores- cent conjugate was performed, followed by a PBS wash and the addition of mounting medium (glycerin $\mathrm{pH}$ 9.6) (Irmen \& Kelleher 2000).

Viral culture - The shell vial cell culture (CC) assay was used to determine the presence of FLUA or FLUB (Maietreyi et al. 2000) in the samples. This technique consists of the use of an MDCK cell monolayer cultured on cover slips in shell vials containing minimal essential medium supplemented with $2 \%$ fetal bovine serum. After discarding the medium, $200 \mu \mathrm{l}$ of the sample was inoculated into a tube containing cover slips with the cell monolayer. The tube was centrifuged at $700 \mathrm{Xg}$ for $40 \mathrm{~min}$. Tubes were supplemented with minimal essential medium containing $1 \%$ trypsin. After incubation at $33^{\circ} \mathrm{C}$ for 48 hours, the cover slip was scraped into a tube, the cells washed once with PBS and the pellet was transferred to a slide. Once dried, the spot was fixed with cold acetone for $10 \mathrm{~min}$. The slide was stained by indirect IF to detect viral replication. Conventional CC methods were used to increase the viral load in order to identify the virus type by using a hemagglutination inhibition (HI) test.

Nucleic acid extraction and cDNA - RNA was extracted from a $150 \mu \mathrm{l}$ sample using guanidinium thiocyanate-silica as described previously. RNA was then converted into cDNA by RT (Boom et al. 1990, Ellis et al. 1997). For RT, $22.2 \mu \mathrm{l}$ of RNA was added to a reaction mixture $(17.8 \mu \mathrm{l})$ containing $20 \mathrm{mM}$ Tris-HCL (pH 8.4), $50 \mathrm{mM} \mathrm{KCL}, 7.5 \mathrm{mM} \mathrm{MgCl}_{2}$ each deoxynucleoside triphosphate at a concentration of $1.5 \mathrm{mM}, 25 \mathrm{ng}$ of each random primers $(\mathrm{pdN})_{6}$ (Pharmacia), $1.6 \mathrm{U}$ of RNasin (Promega), and $200 \mathrm{U}$ of Moloney Murine Leukemia virus reverse transcriptase (Invitrogen) The reaction mixture was incubated at room temperature for $10 \mathrm{~min}, 37^{\circ} \mathrm{C}$ for $45 \mathrm{~min}$ and $95^{\circ} \mathrm{C}$ for $5 \mathrm{~min}$, then quenched on ice.

$P C R$ - During the period of the study, 65 positive samples were selected for subtyping. Multiplex PCR was performed as previously described (Ellis et al. 1997). This involveds the use of primers that hybridize to three different regions of the hemagglutinin (HA) gene related to each FLU type in a single tube. The primers used in the study are described in Table I (Ellis et al. 1997). For

TABLE I

Polymerase chain reaction primers for influenza viruses used in this study

\begin{tabular}{llcc}
\hline Primers & \multicolumn{1}{c}{ Sequence $\left(5^{\prime} \rightarrow 3^{\prime}\right)$} & Position & GeneBank \\
\hline AH1 A & CAGATGCAGACACAATATGT & $54-73$ & CY028724.1 \\
AH1 FII & AAACCGGCAATGGCTCCAAA & $1049-1068$ & CY028724.1 \\
AH3 A & CAGATTGAAGTGACTAATGC & $145-164$ & AB298687 \\
AH3 DII & GTTTCTCTGGTACATTCCGC & $1008-1024$ & AB298687 \\
BHA A & GTGACTGGTGTGATACCACT & $132-151$ & CY030839.1 \\
BHA DII & TGTTTTCACCCATATTGGGC & $1015-1034$ & CY030839.1 \\
AH1 B & ATAGGCTACCATGCGAACAA & $74-93$ & CY028724.1 \\
AH1 EII & CTTAGTCCTGTAACCATCCT & $998-1017$ & CY028724.1 \\
AH3 B & AGCAAAGCTTTCAGCAACTG & $319-338$ & AB298687 \\
AH3 CII & GCTTCCATTTGGAGTGATGC & $890-909$ & AB298687 \\
BHA B & CATTTTGCAAATCTCAAAGC & $174-195$ & CY030855.1 \\
BHA CII & TGGAGGCAATCTGCTTCACC & $930-946$ & CY030855.1 \\
\hline
\end{tabular}


the primary PCR amplification, each primer pair AH1 A and AH1 FII, AH3 A and AH3 DII, and BHA A and BHA DII was used at a concentration of 5 pmol. For the primary PCR, $20 \mu \mathrm{l}$ of cDNA was added to $80 \mu \mathrm{l}$ of a reaction mixture containing $10 \mathrm{mM}$ Tris-HCL (pH 8.8) $3.5 \mathrm{mM}$ $\mathrm{MgCl}_{2}, 25 \mathrm{mM} \mathrm{KCl}$, and $1.5 \mathrm{U}$ of Taq polymerase. Amplification was carried out in an Eppendorf thermocycler with the following cycling conditions: 1 cycle at $94^{\circ} \mathrm{C}$ for $2 \mathrm{~min}$ followed by 35 cycles of $94^{\circ} \mathrm{C}$ for $1 \mathrm{~min}, 50^{\circ} \mathrm{C}$ for $1 \mathrm{~min}$, and then $72^{\circ} \mathrm{C}$ for $1 \mathrm{~min}$. Two microliters of primary product was then transferred to $48 \mu \mathrm{l}$ of the secondary amplification mixture as above using the primers pairs AH1 B and AH1 EII, AH3 B and AH3 CII, BHA B and BHA CII. The amplification was carried out in an Eppendorf thermocycler with the following cycling conditions: 1 cycle at $94^{\circ} \mathrm{C}$ for $2 \mathrm{~min}$ and then 35 cycles of $94^{\circ} \mathrm{C}$ for $1 \mathrm{~min}, 60^{\circ} \mathrm{C}$ for $1 \mathrm{~min}$, and $72^{\circ} \mathrm{C}$ for $1 \mathrm{~min}$. Amplicons were visualized by ethidium bromide staining followed agarose gel electrophoresis and presented approximate sizes of $944 \mathrm{bp}, 591 \mathrm{bp}$, and $767 \mathrm{bp}$ for each primer pair, respectively.

Epidemiological analysis - Temperatures recorded from Serviço de Metereologia do Estado do Paraná and epidemiological data were analyzed using Excel Microsoft and data were obtained by using logistic regression and coefficient of correlation.

\section{RESULTS}

During the study, a total of 1,621 samples were analyzed, corresponding to 273 samples from outpatients and 1,348 samples from hospitalized patients, including 666 from BMT and 682 from the pediatric unit. Among all the samples, $135(8.3 \%)$ were positive for FLU, and of these, 103 (76.3\%) were type A and 32 (23.7\%) were type $\mathrm{B}$, as determined by IF and Shell Vial CC assay. Samples with positive results were verified by conventional CC and viral replication was monitored by hemagglutination using chicken red blood for further analysis by HI. The titers obtained were lower than 1:64, so analysis using HI was inappropriate. A multiplex RT-PCR strategy based on detection of the HA1 portion of the gene of FLUA and FLUB viruses was employed in 65 of the positive samples to further characterize FLU subtypes. Using samples chosen for the analysis, the initial results obtained were the products of amplification with compatible sizes for the subtypes $\mathrm{H} 1 / \mathrm{H} 3$ and $\mathrm{B}$ during the study,

Outpatients showed a higher incidence of positive samples for FLU (20\%) compared to BMT (7.2\%) and pediatric $(4.7 \%)$ inpatients (Fig. 1). Table II shows the total number of positive samples for FLUs, other viruses studied, and the proportion of co-infection expressed in percentages over the four years for outpatients. For the duration of the study, the FLUA was the most frequent. Markedly, in 2000, the FLUA presented a greater percentage incidence than in other years. However, an increasing incidence of FLUB occurred in 2002. During the period of 2000-2002, co-infection was detected with PIV (1.9\%), RSV (4.3\%), and Adenvirus (1.3\%). In the analysis of outpatients, we concluded that there is no statistically significant association between either sex or age and the incidence of infection. Clinical signs and symptoms associated with more than $80 \%$ of cases of infection were rhinorrea, fever, and cough. However, by using logistic regression statistical analysis, fever $(\mathrm{p}=0.0216)$ was determined to be the most significant predictor or the proposed method, followed by myalgia $(\mathrm{p}=0.1233)$.

Among the 273 outpatients, 21 (7.7\%) had received the influenza vaccine in April, a period for vaccination established by the Brazilian Health System. Five (23.8\%) patients were positive for FLUs despite having been vaccinated. Fig. 2 shows the number of positive samples for FLUA and FLUB and the monthly median outdoor temperature during the three year period. It can be observed from the figure that there was an increase in the number of samples that tested positive for FLUA as well as FLUB during the winter season, which is associated with a lower outdoor temperature. The coefficient of correlation derived from our statistical analysis showed an indirect relation between temperature and the number of positive samples for FLUs. Female patients provided

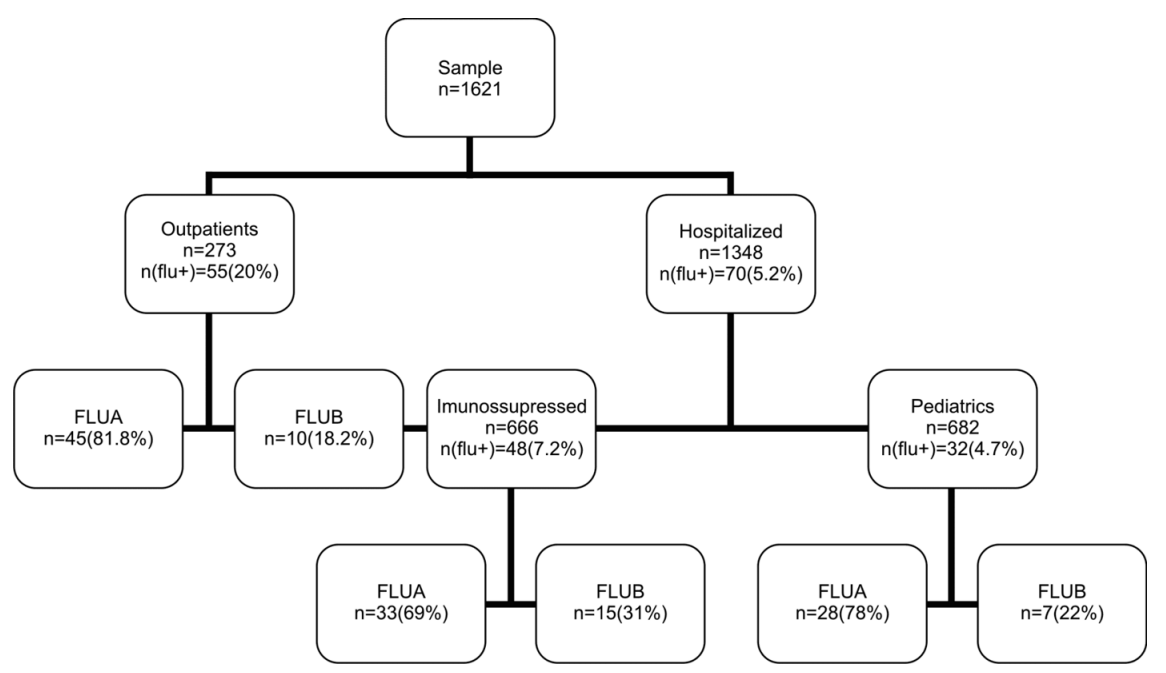

Fig. 1: incidence of influenza viruses (FLU) types A and B in outpatients and hospitalized patients, Curitiba, PR, 2002-2003. 
TABLE II

Immunofluorescence (IF) and cell culture (CC) results for respiratory viruses in outpatients, Curitiba, PR, 2000-2003

\begin{tabular}{lccccc}
\hline & \multicolumn{4}{c}{ IF/CC } \\
\cline { 2 - 6 } Virus & $2000(\mathrm{n}=53)$ & $2001(\mathrm{n}=96)$ & $2002(\mathrm{n}=83)$ & $2003(\mathrm{n}=41)$ & Total $(\mathrm{n}=273)$ \\
\hline Influenza A & $17(32.0 \%)$ & $11(11.5 \%)$ & $6(7.2 \%)$ & $5(12.3 \%)$ & $39(14.3 \%)$ \\
Influenza B & $1(1.9 \%)$ & $1(1.0 \%)$ & $7(8.5 \%)$ & $1(2.4 \%)$ & $10(3.7 \%)$ \\
Co-infection & $1(1.9 \%)^{a}$ & $4(4.3 \%)^{b}$ & $1(1.3 \%)^{c}$ & $0(0 \%)$ & $06(2.2 \%)$ \\
RSV/PIV/Adeno & $6(11.3 \%)$ & $7(7.2 \%)$ & $10(12.0 \%)$ & $4(9.7 \%)$ & $27(9.9 \%)$ \\
Negative & $28(52.9 \%)$ & $73(76 \%)$ & $59(71.0 \%)$ & $31(75.6 \%)$ & $191(9.9 \%)$ \\
\hline
\end{tabular}

$a$ : influenza A/parainfluenza (PIV); $b$ : influenza A/respiratory syncytial virus (RSV); $c$ : influenza A/adenovirus (Adeno).

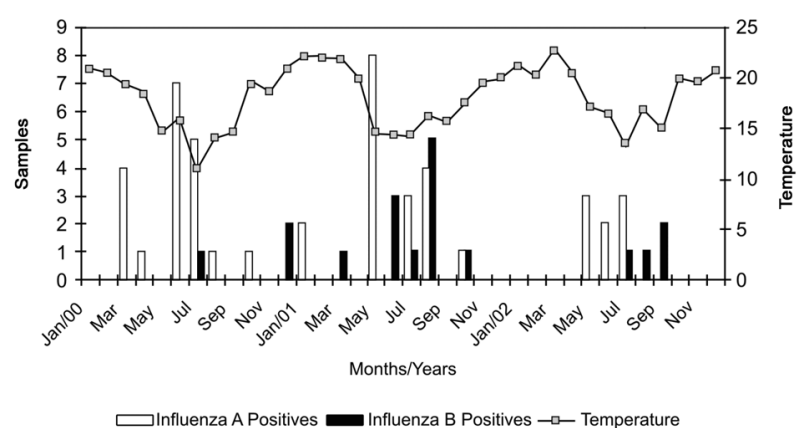

Fig. 2: seasonal distribution of influenza cases in Curitiba, PR, and monthly medium outdoor temperature during 2000 to 2003.

$58.3 \%$ of the samples (data not shown). Pediatric outpatients $(<14$ years old) made up $22 \%$ and immunosuppressed pediatrics patients made up $42 \%$ of the samples. Table III presents the annual influenza virus incidence for immunosuppressed and pediatric patients. The incidence of FLUA and FLUB decreased in the both 2002 and 2003 for both groups and FLUA was the most prevalent in the period of the study. On the other hand, the incidence of FLUB remained relatively high in 2001 for immunosuppressed patients and it can be observed that there was a slight increase in FLUB prevalence in 2002, which is similar to the result seen with outpatients in this year (Table II). When analyzing the frequency of positive outpatient samples and median outdoor temperatures during the period of the study, the pattern observed was the same as the one presented in Fig. 2 for hospitalized patients. We have found an inverse correlation between the median outdoor temperature and the incidence of viral infection.

Respiratory symptoms and clinical signs were collected through the study for pediatric patients. The most frequent clinical symptom presented was dyspnea (51.9\%), followed by fever and cough (48.3 and 44.4\%, respectively). However, only cough $(\mathrm{p}=0.0149)$ was significant for the proposed model, as determined by logistic regression statistical analysis, followed by fever $(\mathrm{p}=0.2452)$. Pediatric patients who presented IRA with influenza as an etiologic agent were analyzed in a clinical setting. Influenza incidence was higher in pediatric patients attended to at the emergency unit and intensive care unit, where one death occurred due to respiratory complications.

\section{DISCUSSION}

According to data collected annually from the health system in Curitiba, 42,000 hospitalizations due to respiratory diseases occurred from 2000 to 2002. The mortality index due to respiratory disease was around $11.5 \%$, pneumonia with a non-specified etiologic agent and obstructive pneumonia were the main causes. The percentage mortality for children from 1 to 4 years old was $17.5 \%$ and for individuals above 50 years old, it was $13.6 \%$. Additionally, data obtained by the local health service indicates a considerable burden of morbidity and mortality due to respiratory diseases occurring in individuals of all ages along with a high degree of pneumonia without an identifiable cause (Ministério da Saúde 2002). The same phenomenon occurs in many countries as described by several authors (Zambon 1999, Neuzil et al. 2003, Lin et al. 2004). In this context, it is important to know the impact of FLUs in the cases of unspecified etiologic agents. This study showed that FLU has an important role in the etiology of acute respiratory diseases among outpatients and hospitalized patients in Curitiba, Southern Brazil. The virus was responsible for $8.4 \%$ of respiratory infections among the patients studied. The majority of positive samples $(88 \%)$ were attributed to FLUA, characterized by IF and a "shell vial" cell cultureCC assay.

The general hospital characteristically attends to the low income population from the Southern region of Brazil. During the period of the study, the hospital attended to a total of 1,034 patients in the BMT unit, 3,582 in the pediatric unit, 1,456 in the pediatric intensive care unit, and 3,096 int the pediatric emergency unit. Our data are relevant for establishing epidemiological and seasonal patterns of FLU in this region in the different groups of patients. It is well known that the FLU contributes to the increased morbidity and mortality seen during the winter months, including data from Brazil (Straliotto et al. 2002, Motta et al. 2006). Moreover, it is estimated that between 5,000 and 29,000 deaths were caused by influenza each year in the United Kingdom between 1975 and 1990, five times the number directly attributed to influenza on death certificates (Stockton et al. 1998, Zambon 1999). In 2000, a high percentage of positive samples were obtained. It is important to point out that it was possible for the same technician to accomplish all the adequate procedures for selection, collection and transport of the samples during this year. We believe 
TABLE III

Immunofluorescence (IF) and cell culture (CC) results for respiratory viruses from immunosupressed patients, Curitiba, PR, 2000-2003

\begin{tabular}{|c|c|c|c|c|c|c|c|c|c|c|}
\hline \multirow{3}{*}{ Virus } & \multicolumn{10}{|c|}{$\mathrm{IF} / \mathrm{CC}$} \\
\hline & \multicolumn{5}{|c|}{ Immunosupressed } & \multicolumn{5}{|c|}{ Pediatrics } \\
\hline & $\begin{array}{c}2000 \\
(n=226)\end{array}$ & $\begin{array}{c}2001 \\
(n=184)\end{array}$ & $\begin{array}{c}2002 \\
(n=159)\end{array}$ & $\begin{array}{c}2003 \\
(\mathrm{n}=97)\end{array}$ & $\begin{array}{c}\text { Total } \\
(\mathrm{n}=666)\end{array}$ & $\begin{array}{c}2000 \\
(n=142)\end{array}$ & $\begin{array}{c}2001 \\
(\mathrm{n}=187)\end{array}$ & $\begin{array}{c}2002 \\
(\mathrm{n}=177)\end{array}$ & $\begin{array}{c}2003 \\
(n=176)\end{array}$ & $\begin{array}{c}\text { Total } \\
(\mathrm{n}=682)\end{array}$ \\
\hline Influenza A & $\begin{array}{c}12 \\
(5.3 \%)\end{array}$ & $\begin{array}{c}10 \\
(5.4 \%)\end{array}$ & $\begin{array}{c}2 \\
(1.3 \%)\end{array}$ & $\begin{array}{c}4 \\
(4.1 \%)\end{array}$ & $\begin{array}{c}28 \\
(4.2 \%)\end{array}$ & $\begin{array}{c}6 \\
(4.2 \%)\end{array}$ & $\begin{array}{c}8 \\
(4.3 \%)\end{array}$ & $\begin{array}{c}4 \\
(2.3 \%)\end{array}$ & $\begin{array}{c}4 \\
(2.3 \%)\end{array}$ & $\begin{array}{c}22 \\
(3.2 \%)\end{array}$ \\
\hline Influenza B & $\begin{array}{c}2 \\
(<1 \%)\end{array}$ & $\begin{array}{c}9 \\
(4.9 \%)\end{array}$ & $\begin{array}{c}3 \\
(1.9 \%)\end{array}$ & $\begin{array}{c}0 \\
(0 \%)\end{array}$ & $\begin{array}{c}14 \\
(2.1 \%)\end{array}$ & $\begin{array}{c}1 \\
(<1 \%)\end{array}$ & $\begin{array}{c}2 \\
(1.0 \%)\end{array}$ & $\begin{array}{c}1 \\
(<1 \%)\end{array}$ & $\begin{array}{c}3 \\
(1.7 \%)\end{array}$ & $\begin{array}{c}07 \\
(1.0 \%)\end{array}$ \\
\hline Co-Infection & $\begin{array}{c}1 \\
(<1 \%)^{a}\end{array}$ & $\begin{array}{c}1 \\
(<1 \%)^{b}\end{array}$ & $\begin{array}{c}3 \\
(1.9 \%)^{b}\end{array}$ & $\begin{array}{c}1 \\
(1.0 \%)^{c}\end{array}$ & $\begin{array}{c}06 \\
(0.9 \%)\end{array}$ & $\begin{array}{c}0 \\
(0 \%)\end{array}$ & $\begin{array}{c}0 \\
(0 \%)\end{array}$ & $\begin{array}{c}2 \\
(1.1 \%)^{b, d}\end{array}$ & $\begin{array}{c}1 \\
(<1 \%)^{b}\end{array}$ & $\begin{array}{c}03 \\
(0.4 \%)\end{array}$ \\
\hline RSV/PIV/Adeno & $\begin{array}{c}68 \\
(30.0 \%)\end{array}$ & $\begin{array}{c}25 \\
(13.6 \%)\end{array}$ & $\begin{array}{c}19 \\
(11.9 \%)\end{array}$ & $\begin{array}{c}19 \\
(19.6 \%)\end{array}$ & $\begin{array}{c}131 \\
(19.6 \%)\end{array}$ & $\begin{array}{c}59 \\
(41.5 \%)\end{array}$ & $\begin{array}{c}66 \\
(35.3 \%)\end{array}$ & $\begin{array}{c}56 \\
(31.6 \%)\end{array}$ & $\begin{array}{c}66 \\
(37.5 \%)\end{array}$ & $\begin{array}{c}247 \\
(36.2 \%)\end{array}$ \\
\hline Negative & $\begin{array}{c}143 \\
(63.3 \%)\end{array}$ & $\begin{array}{c}139 \\
(75.5 \%)\end{array}$ & $\begin{array}{c}132 \\
(83 \%)\end{array}$ & $\begin{array}{c}73 \\
(75.3 \%)\end{array}$ & $\begin{array}{c}487 \\
(73.2 \%)\end{array}$ & $\begin{array}{c}76 \\
(53.5 \%)\end{array}$ & $\begin{array}{c}111 \\
(9.3 \%)\end{array}$ & $\begin{array}{c}114 \\
(64.4 \%)\end{array}$ & $\begin{array}{c}102 \\
(57.9 \%)\end{array}$ & $\begin{array}{c}403 \\
(59.1 \%)\end{array}$ \\
\hline
\end{tabular}

$a$ : influenza A/parainfluenza (PIV); $b$ : influenza A/respiratory syncytial virus (RSV); $c$ : influenza B/parainfluenza (PIV); $d$ : influenza A/adenovirus (Adeno).

that this fact explains the increase in the number of positive samples due to discerning selection, collection, and prompt sample transport.

Meanwhile, a higher incidence of FLUB over FLUA was observed in 2002. In the same period, through the sponsorship of the Brazilian Ministry of Health, Paiva et al. (2002) described an outbreak of FLUB/Hong Konglike strain in Brazil. This virus strain was identified in the South, South-east, Centre-East and Northern regions of the country. Their efforts support the policy of the American Advisory Committee on Immunization Practices, which encourages more widespread administration of the influenza vaccine among children and their household contacts. The same finding was reported by Bellei et al. (2007) in a study describing the patterns of influenza infections in different risk groups in Brazil. These studies support the importance of influenza surveillance and the need to improve the currently low ratio of vaccination among health care workers. It is important to establish the seasonal patterns for the FLUs and choose the appropriate seasonal period to vaccinate the population. Our study has shown that samples positive for the FLU were collected primarily in April in the years 2001 and 2002.

A number of co-infections were observed mainly between FLU and RSV, probably due to a similar pattern of circulation. In light of the seasonal pattern of the two viruses, this co-infection has been reported by many authors (Gilchrist et al. 1994, Stockton et al. 1998, Neuzil et al. 2003). Additionally, the study described by Neuzil et al. (2003) that examined health care use in a population of veterans in the North-west United States in relation to FLU and RSV circulation and demonstrated an annual increase in outpatient visits estimated at 115-136 visits per 1,000 high-risk individuals. However, among those without a high-risk condition, the number of visits fell to 43-67 per 1,000 persons. These circumstances lead to high costs for health services.
The current study showed a high incidence of FLUs for immunocompromised individuals. In 2002, the FLUB showed an increase, which could be related to the outbreak described in Brazil (Paiva et al. 2003). Moreover, in 2001, an increased number of positive samples for FLUB was observed, suggesting that dissemination may have occurred inside the unit since the patients were hospitalized around July and August. These observations reaffirm the importance of persistent surveillance and the need to improve reliable methodologies for viral detection. A number of investigators have described the involvement of viruses in respiratory diseases in immunocompromised patients and a great prevalence of the FLU (Paiva et al. 2001, Ison \& Hayden 2002).

For pediatric patients, our study showed an incidence for the FLU of $11.1 \%$ among all positive samples. Recently, the epidemiological surveillance of FLU in this community has been established (FUNASA 1999). As such, patients from 0-4 years old with influenza-like illness symptoms have been collected. The observed prevalence was $19 \%$ for FLUA and $1.5 \%$ for FLUB; furthermore, co-infection occurred with the RSV and PIV. These findings reinforce the idea of co-circulation described for respiratory viruses (Raboni et al. 2003). A recent study described by Thomazelli et al. (2007) showed the involvement of respiratory viruses in a pediatric population from the South-East of Brazil. The study reported the detection of FLUA in the majority of samples and the circulation at the end of fall/beginning of winter; FLUB was not detected. According to the World Health Organization, respiratory infections, as well as diarrhea, are the main problems of public health, especially among young children. The high rate of mortality in young children due to acute respiratory infections has important distinctions between developed and developing countries (Monto 2002). It has been reported that ARI is the leading cause of death among children in underdeveloped countries (Maietreyi et al. 2000, Vieira et al. 2001, 
Tsuchiya et al. 2005). In this context, our previous study demonstrated that respiratory viruses play an important role in acute respiratory infection (Tsuchiya et al. 2005, Coelho et al. 2007) while the present study describes the high prevalence of viruses in patients receiving differing levels of health care.

Continuous influenza surveillance will contribute to the comprehension of the virus's epidemiology, the establishment of therapeutic strategies in order to minimize the complications caused by the virus, the standardization of diagnostic protocols and awareness of the impact of FLUs in this population.

The results obtained by reverse RT-PCR revealed the prevalence of FLUA subtypes H1 and H3 and FLUB during the period of the study. These samples were selected for further genotypic analyses. FLUs undergo constant antigenic change, hence continuous virological surveillance is important for characterizing the strains. This will enableenables the detection of antigenic similarity between vaccine strains and circulating viruses and thus allows for the selection of antigenic types that should be used in a new vaccine.

\section{REFERENCES}

Bellei N, Carraro E, Perosa A, Granato C 2007. Patterns of Influenza Infections Among Different Risk Groups in Brazil. Braz J Infect Dis 11: 399-402.

Boom R, Sol CJA, Salimans MMM, Jansen CL, Wertheimvan Dillen PME, van derNoordan J 1990. Rapid and Simple Method for Purification of Nucleic Acids. J Clin Microbiol 28: 495-503.

Coelho MC, Tsuchiya LRRV, Nogueira MB, Pereira LA, Takahashi GA, Cruz CR, Raboni SM 2007. Impact of Respiratory Infections by Influenza Viruses A and B in Pediatrics Patients from Federal University of Paraná, Brazil. Braz J Infect Dis 11: 220-223.

Cox MJ, Azevedo RS, Cane PA, Massad E, Medley GF 1998. Seroepidemiological study of respiratory syncytial virus in São Paulo state, Brazil. J Med Virol 55: 234-239.

Ellis JS, Fleming DM, Zambon MC 1997. Multiplex Reverse Transcription-PCR for Surveillance of Influenza A and B Viruses in England and Wales in 1995 e 1996. J Clin Microbiol 35: 2076-2082.

FUNASA-Fundação Nacional de Saúde 1999. Projeto Vigilância Epidemiológica da Influenza no Brasil, Ministério da Saúde, Brasília.

Gardner PS, Mcquillin J 1968. Application of immunofluorescence antibody technique in rapid diagnosis of respiratory syncytial virus infection. Br Med J 3: 340-343.

Gilchrist S, Torok TJ, Gary HEJr, Alexander JP, Anderson LJ 1994. National Surveillance for Respiratoty Syncytial Virus, United States, 1985-1990. J Infect Dis 170: 986-990.

Irmen KT, Kelleher JJ 2000. Use of Monoclonal Antibodies for rapid Diagnosis of Respiratory Viruses in an Community Hospital. Clin Diagn Lab Immunol 3: 396-402.

Ison MG, Hayden FG 2002. Viral infections in immunocompromised patients: what's new with respiratory viruses? Curr Opin Infect Dis 15: 355-367.

Lin YP, Gregory V, Bennett M, Hay A 2004. Recent Changes among Human Influenza Viruses. Virus Res 103: 47-52.
Maietreyi RS, Broor S, Kabra SK, Ghosh M, Seth P, Dar LE, Prasad AK 2000. Rapid Detection of respiratory viruses by centrifugation enhanced cultures from children with acute lower respiratory tract infections. J Clin Virol 16: 41-47.

Ministério da Saúde 2002. Sistema de Informações de Saúde. Available from: http://tabnet.datasus.gov.br.

Monto AS 2002. Epidemiology of Viral Respiratory Infections. Am J Med 112 (Suppl. I): 4-12.

Motta FC, Siqueira MM, Lugon AK, Straliotto SM, Fernández SM, Krawczuk MM 2006. The reappearance of Victoria lineage influenza B virus in Brazil, antigenic and molecular analysis. J Clin Virol 36: 208-214.

Neuzil KM, Griffin MR, Schaffner W 2001. Influenza Vaccine: Issues and Opportunities. Infect Dis Clin North Am 15: 123-141.

Neuzil KM, Maynard C, Griffin MR, Heagerty P 2003. Winter Respiratory Viruses and Health Care Use: A Population-Based Study in the Northwest United States. Clin Infect Dis 37: 201-207.

Paiva TM, Ishida MA, Gonçalves MG, Benega MA, de Souza MC, Cruz AS 2002. Ocurrence of influenza B/Hong Kong-like strains in Brazil, during 2002. Rev Inst Med Trop São Paulo 45: 51-52.

Paiva TM, Ishida MA, Gonçalves MG, Benega MA, Souza COM, Cruz AS 2003. Ocurrence of influenza B/Hong Kong-Like strains in Brazil, during 2002. Rev Inst Med Trop Sao Paulo 45: 1-4.

Paiva TM, Ishida MA, Hanashiro KA, Scolaro RM, Goncalves MG, Benega MA, Oliveira MA, Cruz AS, Takimoto S 2001.Outbreak of Influenza Type A (H1N1) in Iporanga, São Paulo State, Brazil. Rev Inst Med Trop Sao Paulo 43: 311-315.

Raboni SM, Nogueira MB, Tsuchiya LRRV, Takahashi GA, Pereira LA, Pasquini R, Siqueira MM 2003. Respiratory Tract Viral Infections in Bone Marrow Transplant Patients. Transplantation 76: $142-146$.

Stockton J, Ellis JS, Saville M, Clewley JP, Zambon MC 1998. Multiplex PCR for typing and subtyping Influenza and Respiratory Syncytial Viruses. J Clin Microbiol 36: 2990-2995.

Straliotto SM, Siqueira MM, Muller RL, Fischer GB, Cunha MLT, Nestor SM 2002. Viral etiology of acute respiratory infections among children in Porto Alegre, RS, Brazil. Rev Soc Bras Med Trop 35: 283-291.

Thomazelli LM, Vieira S, Leal AL, Sousa TS, Oliveira DBL, Golono MA, Gillio AE, Stwien KE, Erdman DD, Durigon EL 2007. Surveillance of eight respiratory viruses in clinical samples of pediatric patients in southeast Brazil. J Pediatr 83: 422-428.

Tsuchiya LRRV, Dalla-Costa LM, Raboni SM, Nogueira MB, Pereira LA, Rotta I. Takahashi G, Coelho M, Siqueira MM 2005. Viral Respiratory Infection in Curitiba, Southern Brazil. J Infect 51: 401-407.

Vieira SE, Stewein KE, Queiroz DAO, Durigon EL, Törög TJ, Anderson LJ, Miyao CR, Hein N, Botosso VF, Pahl MM, Gilio AE, Okay B 2001. Clinical Patterns and Seasonal Trends in Respiratory Syncytial Virus Hospitalizations in São Paulo, Brazil. Rev Inst Med Trop Sao Paulo 43: 125-131.

Zambon MC 1999. Epidemiology and pathogenesis of Influenza. $J$ Antimicrob Chemoth 44 (Suppl. II): 3-9. 